\title{
The inclusion of herd-year-season by sire interaction in the estimation of genetic parameters in Bonsmara cattle
}

\author{
F.W.C. Neser, ${ }^{\star}$ K.V. Konstantinov and G.J. Erasmus \\ Department of Animal Science, University of the Orange Free State, Bloemfontein, 9300, Republic of South Africa \\ Received 14 November 1995; accepted 26 July 1996
}

\begin{abstract}
Weaning weight records of 24758 Bonsmara calves produced by 503 sires in 30 herds, from 1980 to 1993 , were used to examine the importance of the inclusion of herd-year-season by sire interaction in the estimation of genetic parameters. Three separate models were used in the DFREML analysis of the data. In the first, permanent maternal environment was included as an additional random factor, while in the second, herd-year-season by sire interaction was included, also as an additional random factor. Both these factors were included as additional random factors in the third model. The estimates of the (co)variance components and heritabilities for direct additive $(\mathrm{a})$, maternal additive $(\mathrm{m})$ and additional random factor $(\mathrm{c})$ for the three models analysed, were as follows: $\left(\sigma_{\mathrm{a}}^{2}\right.$ : 138.04, 65.23, 67.46; $\left(\sigma_{\mathrm{m}}^{2}: 84.77,143.80,66.83 ;\left(\sigma_{\mathrm{am}}\right)-57.47,-28.24,-21.97 ;\left(\sigma^{2}\right.\right.$ perm: 73.72,

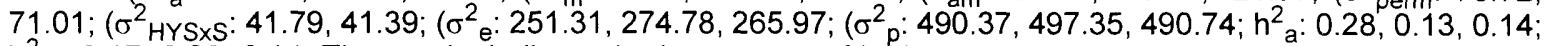
$\mathrm{h}_{\mathrm{m}}^{2}: 0.17,0.29,0.14$. The results indicate the importance of both permanent maternal environment and herdyear-season by sire interaction in the estimation of the genetic parameters. The exclusion of herd-year-season by sire interaction could lead to a serious overestimation of the direct additive components. The same applies for permanent maternal environment. The exclusion of this factor could lead to a serious overestimation of the maternal components. Both these factors should therefore be included in the across-herd weaning weight analysis of Bonsmara cattle.
\end{abstract}

Speengewig rekords van 24758 Bonsmarakalwers, die nageslag van 503 bulle uit 30 kuddes gebore vanaf 1980 tot 1993, is gebruik om die invloed van die insluiting van kudde-jaar-seisoen by vaar interaksie op die beraming van die genetiese parameters te ondersoek. Drie aparte modelle is gebruik in die DFREML analise van die data. In die eerste is permanente maternale omgewingseffekte ingesluit as ' $n$ addisionele toevallige effek. Permanente maternale omgewingseffekte is in die tweede model vervang met kudde-jaar-seisoen by vaar interaksie. In die derde model is beide die faktore as addisionele toevallige effekte ingeluit. Die beramings van die (ko)variansie komponente en oorerflikhede vir direk additief (a), maternaal additief $(\mathrm{m})$ en addisionele toevallige effekte vir die drie modelle gebruik in die analise was soos volg: $\left(\sigma^{2}{ }_{\mathrm{a}}: 138.04,65.23,67.46 ;\left(\sigma^{2} \mathrm{~m}: 84.77,143.80\right.\right.$, 66.83; $\left(\sigma_{a m}:-57.47,-28.24,-21.97\right.$; $\left(\sigma_{\text {perm }}^{2}: 73.72,71.01\right.$; $\left(\sigma_{\text {HYSXS }}^{2}: 41.79,41.39 ;\left(\sigma_{e}^{2}\right.\right.$ : 251.31, 274.78, 265.97; $\left(\sigma^{2}\right.$ : $490.37,497.35,490.74 ; h^{2}$ a: $0.28,0.13,0.14 ; h_{m}{ }_{m}: 0.17,0.29,0.14$. Die resultate dui op die belangrikheid van beide die twee addisionele toevallige effekte in die beraming van die genetiese parameters. Die uitsluiting van kudde-jaar-seisoen by vaar interaksie kan lei tot ' $n$ ernstige oorberaming van die direk additiewe komponente. Dieselfde geld vir permanente maternale omgewing. Die uitsluiting van die effek kan weer op sy beurt lei tot ' $n$ oorberaming van die maternaal additiewe komponente. Beide die effekte behoort dus ingesluit te word in die tussen-kudde analise vir speenmassa van Bonsmarabeeste.

Keywords: Bonsmara cattle, herd-year-season by sire interaction, permanent maternal environment

* To whom correspondence should be adressed

\section{Introduction}

The advances in computer technology and the quest to accurately identify genetically superior animals have led to the use of more complex models in animal breeding. Factors previously unthought of, are now included in the genetic analyses of animals on a regular basis. Weaning weight is, for instance, influenced by a number of additional random factors related to the dam and, if the analysis is done across herds, interactions could be important. All these factors could play a role in the accuracy of the predictions of the genetic parameters and breeding values.

Maternal effects are currently included in almost all genetic evaluations for breeding values in beef cattle owing to their influence on pre-weaning growth traits (Benyshek et al., 1988). Koch (1972) reported that maternally related variance accounts for between $29 \%$ and $38 \%$ of the gain from birth to weaning. Meyer (1992) and Meyer et al. (1993, 1994) illus- trated the importance of including permanent maternal environment in the analysis for weaning weight in Australian beef cattle.

Bonsmara cattle in South Africa are kept under a wide variety of environments that vary from highly intensive feeding systems to near desert grazing. The use of AI across herds has led to the possibility that some sires might have progeny in all of these environments. If a herd-year-season by sire interaction $(\mathrm{HYS} \times \mathrm{S})$ exists, it will influence the accuracy of the estimated genetic parameters and subsequently breeding values. The effect of genotype by environment interaction, or, as in this case, HYS $\times \mathrm{S}$ is well documented (Buchanan \& Nielsen, 1979; Tess et al.,1979; Bertrand et al., 1985, 1987, Brown et al., 1993a, 1993b, Foulley \& Henderson, 1989). Notter et al. (1992) suggested that to obtain accurate across-herd analyses of sires, herd $\times$ sire interaction should always be included.

The object of this study was to examine the effect of the inclusion of both $\mathrm{HYS} \times \mathrm{S}$ interaction and permanent maternal 
environment in the analysis of the genetic parameters for weaning weight in Bonsmara cattle.

\section{Material and methods}

Data

Weaning weight records of 24758 Bonsmara calves, the progeny of 503 sires in 30 herds, were used in the analysis. The period covered was between 7 and 13 years per herd. Most of the herds were from the Northern Transvaal, Free State, North West Province and the Northern Cape. There was, however, also a herd from Namibia. AI was used in all the herds. Genetic links between the herds were therefore present. Editing of the data entailed the following: All sires with less than five progeny were deleted. This meant a loss of about 103 sires but only 261 records. Herd-year-season contempory groups with only one sire were deleted. It was felt that this procedure should be followed since an interaction was to be investigated.

\section{Analysis}

To assess the influence of the non-genetic factors on weaning weight and their inclusion in the model, an analysis of variance was done using Harvey's LSMLMW computer program (Harvey 1988).

Estimates of the (co)variance components were obtained using the derivative-free REML program (DFREML) developed by Meyer $(1991,1995)$. Three separate analyses were performed in order to compare the estimated (co)variance components. In the first, two correlated random factors, direct additive and maternal additive were included, while permanent maternal environment was included as an uncorrelated additional random factor as described by Meyer (1989). Herd-year-season and sex were included as fixed effects. Age of dam and age at weaning were fitted as linear regressors. In the second analysis, permanent maternal environment was replaced with $\mathrm{HYS} \times \mathrm{S}$ interaction. The rest of the factors in the model remained unchanged. In the third analysis both permanent maternal environment and $\mathrm{HYS} \times \mathrm{S}$ interaction were included as additional random factors. Again the rest of the factors in the model did not change.

\section{Results and discussion}

In Table 1 the log likelihood values obtained under the different models of analysis are expressed as deviations from the log likelihood obtained under the most suitable model.

The log likelihood values indicated that analysis 3 (where both permanent maternal environment and $\mathrm{HYS} \times \mathrm{S}$ were included as additional random factors) was the most suitable model to analyse the data.

The heritability and (co)variance component estimates from all three analyses are presented in Table 2.

The estimates of the genetic parameters are in agreement with the summary of the estimates of a variety of breeds given by Meyer (1992).

The inclusion of $\mathrm{HYS} \times \mathrm{S}$ interaction in the second analysis resulted in reducing the direct additive genetic variance estimate by more than $50 \%$. The same applied to maternal additive variance when permanent maternal environment was included in the first analysis. In the third analysis the direct
Table 1 Log likelihood values obtained as deviation from the most suitable model under three different models of analysis

\begin{tabular}{ccc}
\hline Analysis 1 & Analysis 2 & Analysis 3 \\
\hline $465.81^{* *}$ & $99.04^{* *}$ & 0 \\
\hline$* * p<0.01$ & &
\end{tabular}

Table 2 The heritability and (co)variance component estimates obtained in the three analyses

\begin{tabular}{lccc}
\hline & Analysis 1 & Analysis 2 & Analysis 3 \\
\hline Direct heritability & 0.282 & 0.131 & 0.138 \\
SE & 0.025 & 0.030 & 0.000 \\
Maternal heritability & 0.173 & 0.289 & 0.136 \\
SE & 0.021 & 0.030 & 0.020 \\
Covariance as proportion of total variance & -0.117 & -0.057 & -0.045 \\
SE & 0.019 & 0.027 & 0.000 \\
Permanent maternal as additional random & & & \\
factor & 0.150 & - & 0.145 \\
SE & 0.016 & - & 0.015 \\
HYS $\times S$ as additional random factor & - & 0.084 & 0.084 \\
SE & - & 0.007 & 0.000 \\
Direct additive variance & 138.037 & 65.225 & 67.461 \\
Maternal additive variance & 84.773 & 143.803 & 66.831 \\
Covariance between animal effects & -57.472 & -28.246 & -21.917 \\
Variance owing to permanent maternal & 73.720 & - & 71.005 \\
Variance owing to HYS $\times S$ & - & 41.790 & 41.393 \\
Error variance & 251.306 & 274.780 & 265.969 \\
Phenotypic variance & 490.365 & 497.352 & 490.743 \\
Correlation between animal effects & -0.531 & -0.292 & -0.326 \\
\hline
\end{tabular}

additive variance was lower than in the first analysis, but slightly higher than the second. The maternal additive variance was, however, lower than in both the first and second analysis. The same applied for the two additional random factors, which were also the lowest in the third analysis.

The HYS $\times \mathrm{S}$ interaction effect in the third analysis is approximately $61 \%$ of the direct additive variance and approximately $8.4 \%$ of the phenotypic variance. This is higher than the 3.3 to $6.2 \%$ obtained by Notter et al. (1992) as well the 2.2 to $4.0 \%$ obtained by Bertrand et al. (1985) and Tess et al. (1979). The permanent maternal environmental variance in the third analysis is $6 \%$ higher than the maternal additive variance. It is also approximately $14.5 \%$ of the phenotypic variance. This value is higher than that obtained by Meyer (1992). The $14.5 \%$ would suggest that permanent maternal environment is the more important one of the two additional random factors. This is, however, not true, since the log likelihood values for analysis 2 are lower than that of analysis 1; also, the exclusion of the HYS $\times$ S could lead to a serious overestimation of the additive genetic trend as can be seen in Figure 1.

The linear regression analysis of the average yearly breeding values shows a yearly increase of $50 \mathrm{~g}$ in the additive genetic value of weaning weight when $\mathrm{HYS} \times \mathrm{S}$ is included in the model in both the second and third analyses. This is in 


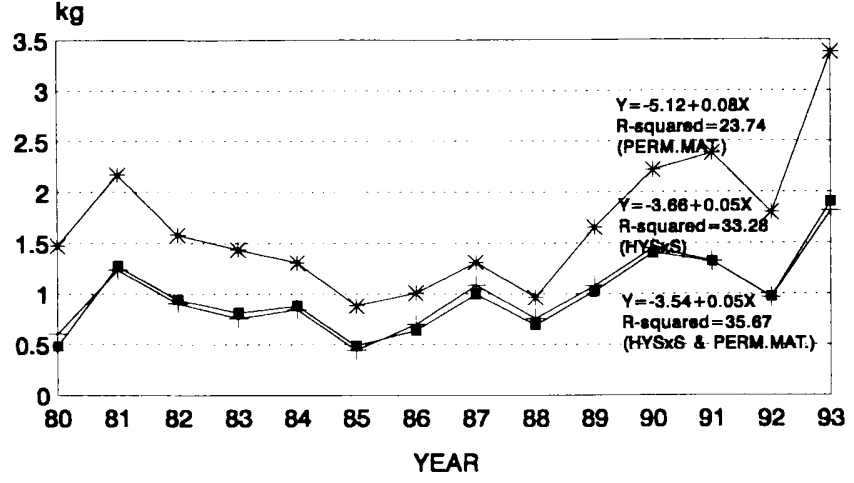

+ HYSXS * PERM. MAT. - HYSXS \& PERM. MAT.

Figure 1 Average annual direct additive breeding values for weaning weight in 30 Bonsmara herds.

contrast to the $80 \mathrm{~g}$ when only permanent maternal environment is included. The result is an apparent overestimation of $30 \mathrm{~g}$ per year.

However, the exclusion of permanent maternal environment could also lead to bias in the estimation of the maternal trend for weaning weight, as seen in Figure 2.

According to Robertson (1959) the differences in the performance of an animal in different environments is of biological importance when the genetic correlation between the performance in the different environments is less than 0.8 . The intraclass genetic correlation between performance of daughters of a sire in different herds can be written as $\mathrm{t}=\left(\sigma_{\mathrm{s}}^{2} /\right.$ $\left(\sigma_{\mathrm{s}}^{2}+\sigma_{\mathrm{c}}^{2}\right.$ ) (where $\sigma_{\mathrm{s}}^{2}$. equalsthe sire variance and $\sigma_{\mathrm{c}}^{2}$ equals the variance owing to the interaction). Since $\left(\sigma_{\mathrm{s}}^{2}=\sigma_{\mathrm{a}}^{2} / 4, \mathrm{t}=\right.$ $\sigma_{\mathrm{a}}^{2} /\left(\sigma_{\mathrm{a}}^{2}+4 \sigma_{\mathrm{c}}^{2}\right)$, where $\sigma_{\mathrm{a}}^{2}$ equals the direct additive variance. In the third analysis a genetic correlation of 0.29 was obtained. This clearly indicates a genotype $\times$ environment interaction and would validate the inclusion of the HYS $\times$ S as an additional random factor in the model. Meyer (1987) reported that the exclusion of even a small genotype $\times$ environment interaction can lead to an overestimation of the accuracy of the sire's predicted breeding value.

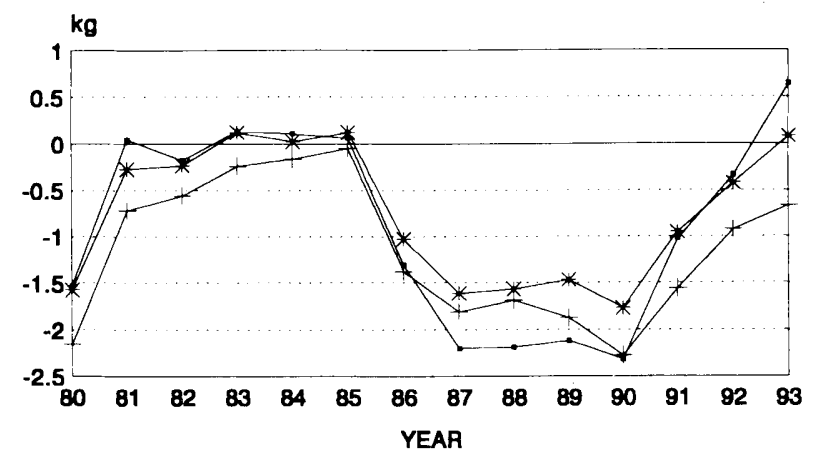

- HYSXS + PERM. MAT. * HYSXS \& PERM. MAT.

Figure 2 Average annual maternal additive breeding values for weaning weight in 30 Bonsmara herds.

\section{Conclusions}

This study shows the importance of the inclusion of both permanent maternal environment and $\mathrm{HYS} \times \mathrm{S}$ in the analysis of weaning weight across herds. Permanent maternal environment, including additive maternal effects, is nearly completely made up of the milk production capabilities of the cow (Meyer et al., 1994), and could thus be used in the selection for milk production in future generations. The interaction, on the other hand, could identify sires that are more adapted to specific regions. This could resolve the problem of sires whose progeny performs well in one region, but fails to perform in another. The exclusion of any of these two factors could lead to bias in the estimation of the genetic parameters for weaning weight.

\section{Acknowledgements}

The authors thank the Director, Animal Improvement Institute of the ARC for kind permission to use the data. Mr D.J. Bosman of the ARC is thanked for his personal assistance.

\section{References}

BENYSHEK, L.L., JOHNSON, M.H., LITTLE, D.E., BERTRAND, J.K. \& KRIESE, L.A., 1988. Application of an animal model in the United States beef cattle industry. J. Dairy Sci. 71(suppl. 2), 35 .

BERTRAND, J.K., BERGER, P.J. \& WILLHAM, R.L., 1985. Sire $\times$ environment interaction in beef cattle weaning weight field data. J. Anim. Sci. 60,1396.

BERTRAND, J.K.. HOUGH, J.D. \& BENYSHEK, L.L., 1987. Sire $x$ environment interaction and genetic correlations of sire progeny performance across regions in dam-adjusted field data. J. Anim. Sci. 64,77.

BROWN, M.A., THAREL, L.M., BROWN, A.H. JR., JACKSON, W.G. \& MEISNER, J.R., 1993a. Genotype $\times$ environment interactions in pre-weaning traits of purebred and reciprocal cross Angus and Brahman calves on common Bermuda grass and endophyte-infected tall fescue pastures. J. Anim. Sci. 71,326.

BROWN, M.A. BROWN, A.H. JR., JACKSON, W.G. \& MEISNER, J.R., 1993b. Genotype $\times$ environment interaction in postweaning performance to yearling in Angus, Brahman and reciprocal-cross calves. J. Anim. Sci. 71,3273.

BUCHANAN, D.S. \& NIELSEN, M.K., 1979. Sire by environment interaction in beef cattle field data. J. Anim. Sci. 48,307.

FOULLEY, J.L. \& HENDERSON, C.R., 1989. A simple model to deal with sire by treatment interaction when sires are related. $J$. Dairy Sci. 72, 167.

HARVEY, W.R., 1988. User's guide for LSMLMW (PC-1 version). Mixed model least squares and maximum likelihood computer program. Ohio State Univ., Ohio, USA.

KOCH, R.M., 1972. The role of maternal effects in animal breeding: VI. Maternal effects in beef cattle. J. Anim. Sci. 35,1316.

MEYER, K., 1987. Estimates of variance due to sire $\times$ herd interaction and environmental covariances between paternal halfsibs for first lactation dairy production. Live. Prod. Sci., 17,95.

MEYER, K., 1989. Restricted maximum likelihood to estimate variance components for animal models with several random effects using a derivative-free algorithm. Genet. Sel. Evol. 21,317.

MEYER, K., 1991. Estimating variance and covariances for multivariate animal models by restricted maximum likelihood. Genet. Sel. Evol. 23,67.

MEYER, K., 1992. Variance components due to direct and maternal effects for growth traits of Australian beef cattle. Livest. Prod. Sci. 31,179 . 
MEYER, K., 1995. DFREML programs to estimate variance components by restricted maximum likelihood using a derivativefree algorithm - User notes.

MEYER, K., CARRICK, M.J. \& DONNELLY, B.J.P., 1993.

Genetic parameters for growth traits of Australian beef cattle from a multibreed selection experiment. J. Anim. Sci. 71, 2614.

MEYER, K., CARRICK, M.J. \& DONNELLY, B.J.P., 1994. Genetic parameters for milk production of Australian beef cows and weaning weight of their calves. J. Anim. Sci. 72,1155.
NOTTER, D.R., TIER, B. \& MEYER, K., 1992. Sire $\times$ herd interactions for weaning weight in beef cattle. J. Anim. Sci. $1992,2359$.

ROBERTSON, A., 1959. The sampling variance of the genetic correlation coefficient. Biometrics 15, 469.

TESS, M.W., KRESS, D.D., BURFENING, P.J. \& FRIEDRICH, R.L., 1979. Sire by environment interaction in Simmental-sired calves. J. Anim. Sci. 49, 965. 